\title{
Calculated Mineral Reactions in the Earth's Mantle
}

\author{
Thomas J. Ahrens \\ Poulter Laboratories, Stanford Research Institute \\ Menlo Park, California 94025 \\ YASUHIKo SYONO ${ }^{1}$ \\ Geophysics Department, Stanford University \\ Stanford, California
}

\begin{abstract}
Thermochemical and compressibility data are used to calculate the approximate pressures and temperatures required for the reaction of clinoenstatite to $\mathrm{Mg}_{2} \mathrm{SiO}_{4}$ (spinel or olivine) or to periclase and stishovite, the reaction of forsterite to $\mathrm{Mg}_{2} \mathrm{SiO}_{4}$ (spinel) or periclase and stishovite, and the breakdown of $\mathrm{Mg}_{2} \mathrm{SiO}_{4}$ (spinel) to periclase and stishovite. The calculated reaction lines for $\mathrm{Mg}_{2} \mathrm{SiO}_{6}$ (olivine) $\rightarrow 2 \mathrm{MgO}+\mathrm{SiO}_{2}$ and $\mathrm{MgSiO}_{3} \rightarrow \mathrm{MgO}+\mathrm{SiO}_{2}$ are $p=$ $199 \pm 17+0.021 T$ and $p=182 \pm 17+0.024 T$ ( $p$ in kilobars and $T$ in degrees Celsius). These reaction lines lie at higher pressures than previously estimated. Because of the formation of $\mathrm{Mg}_{2} \mathrm{SiO}_{4}$ (spinel) these two reactions probably do not take place in the earth's mantle. It appears, rather, that the reactions $\mathrm{Mg}_{2} \mathrm{SiO}_{4}$ (olivine) $\rightarrow \mathrm{Mg}_{2} \mathrm{SiO}_{4}$ (spinel), $\mathrm{Mg}_{2} \mathrm{SiO}_{4}$ (spinel) $\rightarrow 2 \mathrm{MgO}+\mathrm{SiO}_{2}$, and $2 \mathrm{MgSiO}_{8} \rightarrow \mathrm{Mg}_{2} \mathrm{SiO}_{4}$ (spinel) $+\mathrm{SiO}_{\text {s }}$ take place along $p=110 \pm$ $11+0.024 T, p=321 \pm 38-0.013 T$, and $p=133 \pm 19+0.039 T$, respectively.
\end{abstract}

Introduction. The stability of clinoenstatite $\left(\mathrm{MgSiO}_{3}\right)$ and forsterite $\left(\mathrm{Mg}_{2} \mathrm{SiO}_{4}\right)$ from 100 to $350 \mathrm{~kb}$ is examined on the basis of studies of their reactions under static high pressure, available thermochemical data, and static and dynamic pressure-volume data. (Clino- rather than orthoenstatite was studied because thermodynamic data are available only for clinoenstatite.) A material having the composition of clinoenstatite and forsterite, with perhaps 8-10\% FeO, has long been thought to represent the composition of the upper mantle. This assumption has been based on the physical properties of these minerals, the structural relations that occur where ultramafic materials are present in the crust, and geochemical abundance data (based largely on meteorite compositions). Recently Birch [1964] has demonstrated that the pressure-density Hugoniot curves up to $1.1 \mathrm{Mb}$ for rocks such as eclogite, bronzite, and dunite (containing the above minerals) agree closely with the pressuredensity curves calculated for the upper mantle (the latter are based on Birch's [1961] compressional velocity-density correlation for rocks

${ }^{1}$ On leave from Institute for Solid State Physics, University of Tokyo, Tokyo, Japan. and minerals of low mean atomic weight). The pressure range $(100-350 \mathrm{~kb})$ in which the stability of $\mathrm{MgSiO}_{3}$ and $\mathrm{Mg}_{2} \mathrm{SiO}_{4}$ are examined corresponds to depths in the earth of 200-900 $\mathrm{km}$. Over this depth range a marked increase in longitudinal and transverse elastic wave velocities has been inferred from travel-time data [Bullen, 1956] and more recently from surface wave dispersion and free oscillation data [Anderson, 1965]. These velocity increases, as Birch [1952] has pointed out, are reflected in a marked increase in the value of $K / \rho$ (bulk modulus/density).

Birch [1952], Ringwood [1962], MacDonald [1962], and others have suggested that reactions involving the breakdown of clinoenstatite and forsterite to minerals with more closely packed oxide structures at depths between 200 and $900 \mathrm{~km}$ give rise to the observed change in elastic properties over this interval. The pressure-temperature lines along which some of these reactions should take place are calculated here. Studies of the elastic velocities in rocks and minerals [Birch, 1960, 1961; Simmons, 1964] suggest that reactions resulting in closely packed oxide structures would account for the sharp increase in the values of $K / \rho$ from values of the order of $30(\mathrm{~km} / \mathrm{sec})^{2}$ (typical of open 
structure silicates, above depths $200 \mathrm{~km}$ in the earth, such as forsterite and clinoenstatite) to those of the oxides (such as periclase and stishovite) for which the values of $K / \rho$ are of the order of $60(\mathrm{~km} / \mathrm{sec})^{2}$.

Calculational approach. The increase of free energy, $\Delta F_{208}{ }^{\circ}$, at zero pressure and $298^{\circ} \mathrm{K}$ of the reactions listed in Table 1 was calculated from thermodynamic identity

$$
\Delta F_{298}{ }^{\circ}=\Delta H_{298}{ }^{\circ}-298 \Delta S_{298}{ }^{\circ}
$$

where $\Delta H_{209}{ }^{\circ}$ and $\Delta S_{209}{ }^{\circ}$ are the change in enthalpy and entropy of the reaction at zero pressure and $298^{\circ} \mathrm{K}$. The superscript and the subscript indicate the appropriate pressure and temperature, respectively. The pressure required to decrease the free energy to zero along an isotherm (such as $298^{\circ} \mathrm{K}$ ) is implicitly given by

$$
0=\Delta F_{298}{ }^{D}=\int_{0}^{p} \Delta V d p+\Delta F_{298}{ }^{\circ}
$$

where $\Delta V$ is the change in volume of the reacting material and $p$ is the equilibrium pressure at $298^{\circ} \mathrm{K}$.

In previous calculations [Ringwood, 1962;

TABLE 1. Calculated $p-T$ Reaction Lines

\begin{tabular}{|c|c|c|}
\hline Reactions & $p_{0}, \mathbf{k b}$ & $\begin{array}{c}a, \\
\mathrm{~kb} /{ }^{\circ} \mathrm{C}\end{array}$ \\
\hline 1. $\underset{\text { (stishovite) }}{\mathrm{SiO}_{2} \text { (coesite) }} \rightarrow \mathrm{SiO}_{2}$ & $\begin{array}{c}96 \\
(89-103)^{a}\end{array}$ & 0.021 \\
\hline $\begin{array}{c}\text { 2.b } \mathrm{Mg}_{2} \mathrm{SiO}_{4} \text { (forsterite) } \rightarrow \\
2 \mathrm{MgO}+\mathrm{SiO}_{2} \\
\text { (stishovite) }\end{array}$ & $\begin{array}{c}199 \\
(183-216)\end{array}$ & 0.021 \\
\hline $\begin{array}{c}\text { 3.c } \mathrm{MgSiO}_{2} \text { (clinoenstatite) } \rightarrow \\
\mathrm{MgO}+\mathrm{SiO}_{2} \\
\text { (stishovite) }\end{array}$ & $\begin{array}{c}182 \\
(166-199)\end{array}$ & 0.024 \\
\hline 4. $\begin{array}{r}\mathrm{Mg}_{2} \mathrm{SiO}_{4} \text { (forsterite } \rightarrow \\
\mathrm{Mg}_{2} \mathrm{SiO}_{4} \text { (spinel) }\end{array}$ & $\begin{array}{c}110 \\
(99-120)\end{array}$ & 0.050 \\
\hline 5. $\begin{array}{l}\mathrm{Mg}_{2} \mathrm{SiO}_{4}(\text { spinel }) \rightarrow \\
2 \mathrm{MgO}+\mathrm{SiO}_{2} \\
\text { (stishovite) }\end{array}$ & $\begin{array}{c}321 \\
(283-359)\end{array}$ & -0.013 \\
\hline 6.c $\begin{aligned} & 2 \mathrm{MgSiO}_{3} \text { (clinoenstatite) } \\
& \rightarrow \mathrm{Mg}_{2} \mathrm{SiO}_{4} \text { (forsterite) } \\
&+\mathrm{SiO}_{2} \text { (stishovite) }\end{aligned}$ & $\begin{array}{c}159 \\
(120-200)\end{array}$ & 0.029 \\
\hline $\begin{array}{l}\text { 7. } 2 \mathrm{MgSiO}_{3} \text { (clinoenstatite) } \\
\overrightarrow{\mathrm{SiO}_{2} \text { (stishovite) }} \mathrm{Mg}_{2} \mathrm{SiO}_{4} \text { (spinel) }+\end{array}$ & $\begin{array}{c}133 \\
(114-153)\end{array}$ & 0.039 \\
\hline
\end{tabular}
$p(\mathrm{~kb})=p_{0}+a T\left({ }^{\circ} \mathrm{C}\right)$

a Range of uncertainty.

- Metastable with respect to reaction 4.

- Metastable with respect to reaction 7.
MacDonald, 1962; Sclar et al., 1964], the calculated pressures required for various reactions and phase changes were obtained by assuming that $\Delta V$ for the reaction is a constant independent of pressure. In the case in which the reactants and products have markedly different compressibility curves (e.g., reactions 2, 3 , and 4 of Table 1) the constant volume change assumption may give rise to a considerable error in calculating the free energy change. Because isothermal pressure-volume data are not yet available for all the mineral species that occur in reactions of interest, we have estimated the pressure-volume curves for use in evaluating the integral in equation 2 so as to obtain refined estimates of the reaction pressures.

The slope of the reaction line, $d p / d T$ (which is assumed to be a constant), was calculated from the Clausius-Clapeyron equation. The value of $\Delta S / \Delta V$ was calculated at ambient conditions from the thermochemical data (Table 2 and Table 3). In general, none of the reactions listed in Table 1 passes through (or even comes close to) the point $T=298^{\circ} \mathrm{K}$ and $p=0$, and so, following Stishov [1963], we make the additional assumption that $\Delta S / \Delta V$ is constant (independent of pressure) along the line $T=298^{\circ} \mathrm{K}$.

Calculating free energy as a function of pressure. Isothermal pressure-volume curves for the minerals involved in reactions 1-7 of Table 1 up to several hundred kilobars have not yet been reported, except for periclase [PerezAlbuerne and Drickamer, 1965]. Hugoniot data for the minerals taking part in these reactions, or for closely related ones, are, however, available and can be used to infer the pressure-volume relations shown in Figure 1. The small offset to slightly higher pressures, at a given volume, of the Hugoniot curve of nonporous minerals relative to the isothermal pressurevolume curves is neglected. The magnitude of the Hugoniot curve offset from the isothermal pressure-volume curve can be estimated for quartz and periclase from data given by Wackerle [1962] and Ahrens [1966].

The low-pressure Hugoniot data for the Ontario augite and the Twin Sisters dunite [Ahrens et al., 1966] were cast in terms of $z=V / V_{0}$ versus pressure, where $V$ and $V_{0}$ are the volumes at high and ambient pressure, respec- 
TABLE 2. Measured Thermochemical Data

\begin{tabular}{|c|c|c|c|c|}
\hline Mineral & $\begin{array}{c}\text { Density } \\
\rho, \\
\mathrm{g} / \mathrm{cm}^{3}\end{array}$ & $\begin{array}{c}\text { Molar } \\
\text { Volume, } \\
\mathrm{cm}^{3} / \text { mole }\end{array}$ & $\begin{array}{c}\text { Standard Heat } \\
\text { of Formation, } \\
\Delta H_{298^{0}} \\
\mathbf{k c a l} / \mathrm{mole}\end{array}$ & $\begin{array}{c}\text { Standard } \\
\text { Entropy, } \\
\boldsymbol{S}_{288^{0}}, \\
\text { cal/mole }{ }^{\circ} \mathbf{K}\end{array}$ \\
\hline $\mathrm{SiO}_{2}$ (quartz) & $2.648^{a}$ & 22.69 & $-217.5^{b, c} \pm 0.4$ & $10.00^{d, 0}$ \\
\hline $\mathrm{MgSiO}_{3}$ (clinoenstatite) & $3.190^{a}$ & 31.47 & $-369.9^{r} \pm 0.7$ & $16.19^{d}$ \\
\hline $\mathrm{Mg}_{2} \mathrm{SiO}_{4}$ (forsterite) & $3.214^{a}$ & 43.79 & $-520.0^{r} \pm 0.8$ & $22.73^{d}$ \\
\hline MgO(periclase) & $3.584^{a}$ & 11.25 & $-143.7^{\circ} \pm 0.1$ & $6.44^{\sigma}$ \\
\hline
\end{tabular}

a Clark [1966].

${ }^{b}$ Good [1962].

- Wise et al. [1962].

${ }^{\circledR}$ Kelley and King [1961].

- JANAF tables [1960].

$f$ Torgesson and Sahama [1948].

- Barron et al. [1959].

tively. These curves were corrected to the initial density of forsterite and clinoenstatite, assuming that the volumes of these minerals are given by

$$
V^{\prime}=z V_{0}^{\prime}
$$

where $V^{\prime}$ and $V_{0}^{\prime}$ are now the compressed and initial volume. One difficulty with using the dunite and augite Hugoniot data is that they give anomalous compressions above $100 \mathrm{~kb}$. These are thought to arise from the onset of reactions of the type discussed below. The volumes inferred from the curves in Figure 1 are likely to be slightly lower than they would be if the material remained completely untransformed in the shock experiments.

Initially, we attempted to infer a pressurevolume curve for the $\mathrm{Mg}_{2} \mathrm{SiO}_{4}$ (spinel) by cast- ing the recent data of McQueen and Marsh [Clark, 1966] for $\mathrm{MgAl}_{2} \mathrm{O}_{4}$ and $\mathrm{Fe}_{9} \mathrm{O}_{4}$ above 600 $\mathrm{kb}$ in terms of $z$ versus $p$. We then fitted those data (which for both minerals fell in the same curve in the $z-p$ plane) to a Murnaghan equation of the form

$$
p=A\left[z^{\gamma}-1\right]
$$

We obtained the constants $A=135.0$ and $\gamma=$ 5.45 for $\mathrm{MgAl}_{2} \mathrm{O}_{4}$ and $A=207.9$ and $\gamma=4.44$ for $\mathrm{Fe}_{3} \mathrm{O}_{4}$. The curves defined by these constants give a considerably higher compression in the range 0 to $29 \mathrm{~kb}$ than do Bridgman's [1949] data for $\mathrm{Fe}_{3} \mathrm{O}_{4}$ and $\mathrm{MgO}$. (When reduced to the $z$ versus $p$ plane, the data for $\mathrm{MgO}$ and $\mathrm{Fe}_{3} \mathrm{O}_{4}$ are essentially identical below $29 \mathrm{~kb}$.) The anomalously higher compressions indicated by the high-pressure shock wave results for

\begin{tabular}{|c|c|c|c|c|c|}
\hline Mineral & & $\begin{array}{c}\text { Density } \\
\rho, \\
\mathrm{g} / \mathrm{cm}^{3}\end{array}$ & $\begin{array}{c}\text { Molar } \\
\text { Volume, } \\
\mathrm{cm}^{3} / \mathrm{mole}\end{array}$ & $\begin{array}{c}\text { Standard Heat } \\
\text { of Formation } \\
\Delta H_{298^{0}} \\
\mathrm{kcal} / \mathrm{mole}\end{array}$ & $\begin{array}{c}\text { Standard } \\
\text { Entropy } \\
S_{298}{ }^{\circ} \\
\text { cal/mole }{ }^{\circ} \mathrm{K}\end{array}$ \\
\hline $\mathrm{SiO}_{2}$ (coesite) & & $2.911^{a}$ & 20.64 & \multirow{3}{*}{$\begin{array}{c}-216.8 \\
-206.0 \\
(-205.3,-206.7)^{\mathrm{c}} \\
-512.5 \\
(-513.2,-511.7)\end{array}$} & 9.45 \\
\hline $\mathrm{SiO}_{2}$ (stishovite) & - & $4.287^{a}$ & 14.02 & & 6.13 \\
\hline $\mathrm{Mg}_{2} \mathrm{SiO}_{4}$ (spinel) & & $3.53^{b}$ & 39.86 & & 18.0 \\
\hline
\end{tabular}

TABLE 3. Calculated Thermochemical Data

\footnotetext{
a Clark [1966].

${ }^{-}$Ringwood and Major [1966b].

- Range of uncertainty.
} 


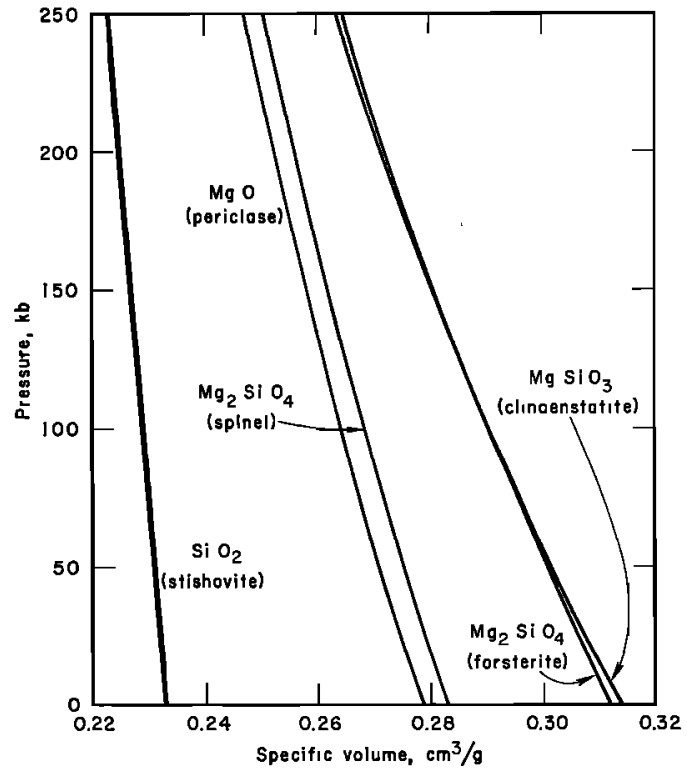

Fig. 1. Pressure-volume curves for reactants used in calculations.

$\mathrm{MgAl}_{2} \mathrm{O}_{4}$ suggest, as R. G. McQueen (private communication, 1966) has pointed out, that these points represent material that is partly or wholly transformed to denser polymorphs. A likely structure for the normal spinel, $\mathrm{MgAl}_{2} \mathrm{O}_{4}$ and $\mathrm{Mg}_{2} \mathrm{SiO}_{4}$, and the inverse spinel, $\mathrm{Fe}_{3} \mathrm{O}_{4}$, to transform to is the hexagonal nickelarsenide structure. This structure is suggested by the recent work of Albers and Rooymans [1965]. (See note added in proof.) Because the $z$ versus $p$ curves for $\mathrm{MgO}$ and $\mathrm{Fe}_{3} \mathrm{O}_{4}$, both closely packed oxides, are similar at low pressures, the pressure-volume curve for $\mathrm{Mg}_{2} \mathrm{SiO}_{4}$ (spinel) should be approximated by the $z$ versus $p$ data for $\mathrm{MgO}$ of Perez-Albuerne and Drickamer [1965]. A lattice parameter for $\mathrm{Mg}_{2} \mathrm{SiO}_{4}$ (spinel) of $8.09 \mathrm{~A}\left(\rho_{0}=3.53 \mathrm{~g} / \mathrm{cm}^{3}\right)$ [Ringwood and Major, 1966b] was assumed in the present calculations. This value is in agreement with the value obtained by Sclar and Carrison [1966] but slightly higher than that obtained by $A k i$ moto and Fujisawa [1966] and Akimoto and Ida [1966].

The pressure-volume curve for stishovite was obtained by assuming, as was first suggested by McQueen et al. [1963], that Wackerle's [1962] Hugoniot points above $400 \mathrm{~kb}$ represent pressure-volume points for stishovite. We have con- nected these Hugoniot data between 414 and $725 \mathrm{~kb}$ to the volume at ambient pressure reported in Clark [1966].

The pressure-volume curve for coesite was estimated by taking the volume of coesite to be given by $V=z V_{0}^{\prime}$ at a given pressure, where $V_{0}^{\prime}$ is the initial volume of coesite [Clark, 1966]. Because of the relatively minor structural rearrangement of coesite relative to quartz, the values of $z$ versus $p$ are assumed to be equal to the values for quartz obtained by Bridgman [1948]. The change in free energy in the $p-T$ plane along the line $T=298^{\circ} \mathrm{K}$ for the reactions listed in Table 1 are plotted in Figure 2. They are calculated by using equation 2 and the pressure-volume curves shown in Figure 1.

Available and calculated thermochemical data. The published thermochemical data that we have used directly in the present calculations are shown in Table 2. The values of $S_{290}{ }^{\circ}$ and $\Delta H_{208}{ }^{\circ}$ for quartz and periclase have been measured by several workers and are believed to be established within the small uncertainties indicated. The data for clinoenstatite and forsterite are less reliable. The measurements, particularly of $\Delta H_{208}^{\circ}$, were performed on either natural crystals or impure synthetic specimens, and the uncertainties indicated are with respect to the standard enthalpies of $\mathrm{MgO}$ and $\mathrm{SiO}_{2}$ (quartz).

In calculating the values of $\Delta H_{208}{ }^{\circ}$ and $S_{298}{ }^{\circ}$ for coesite and stishovite, we applied an approach somewhat similar to that of Stishov [1963] except that: (1) the change in $\Delta V$ with pressure for the reaction is taken into account in evaluating equation 2 ; (2) the value of $\Delta H_{208}{ }^{0}$ for the three $\mathrm{SiO}_{2}$ polymorphs (quartz, coesite, and stishovite) used in the earlier calculations has been corrected (these values were uniformly low by approximately $5 \mathrm{kcal} / \mathrm{mole}$ as a result of an error in measuring $\Delta H_{280}{ }^{\circ}$ for quartz); and (3) revised, more accurate values for the density of coesite and stishovite at ambient pressure are used.

The change in entropy for the reaction (quartz $\rightarrow$ coesite) is calculated by means of Boyd and England's [1960] determination of $d p / d T$ for the reaction and the ClausiusClapeyron equation. The change in enthalpy at $T=298^{\circ} \mathrm{K}$ and ambient pressure is then calculated from equation 1 ; here $\Delta F_{209}{ }^{\circ}$ is obtained from knowledge of the function 


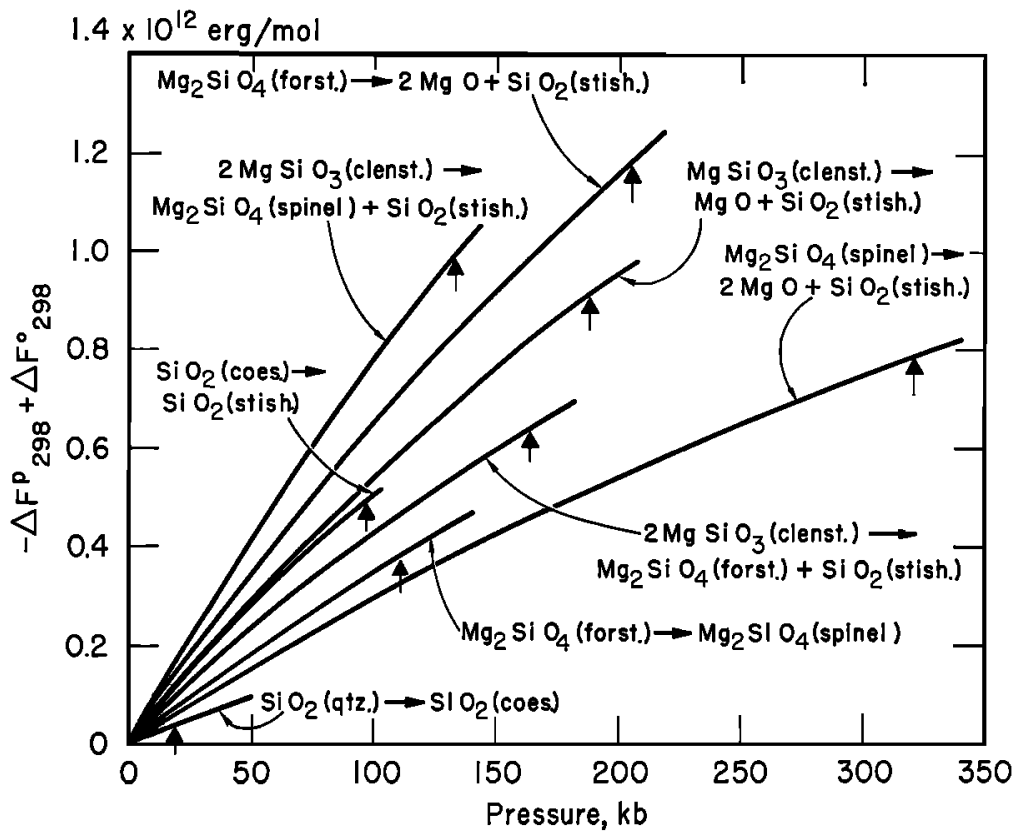

Fig. 2. $-\Delta F_{288}^{p}+\Delta F_{299}{ }^{\circ}$ versus pressure for high-pressure reactions. (Arrows indicate equilibrium pressure, i.e., pressure at which equation 2 is satisfied.) Abbreviations: qtz., quartz; coes., coesite ; forst., forsterite; clenst., clinoenstatite ; stish., stishovite.

$$
\left(-\Delta F_{298}{ }^{p}+\Delta F_{298}{ }^{0}\right)=-\int_{0}^{D} \Delta V d p
$$

versus $p$ (plotted in Figure 2) and the reaction pressure of $19.5 \mathrm{~kb}$ at $298^{\circ} \mathrm{K}$ [Boyd and England, 1960]. Since $d p / d T$ for the reaction coesite $\rightarrow$ stishovite has not yet been experimentally determined, the standard entropy of stishovite must be independently estimated [Stishov, 1963]. For this we have used the value given in Clark [1966] for the ambient density of stishovite and the correlation of density with entropy in the isostructural series of $\mathrm{PbO}_{2}, \mathrm{SnO}_{2}$, and $\mathrm{GeO}_{2}$ frst used by Stishov. Using the value of $S_{203}{ }^{0}$ thus obtained for stishovite in the Clausius-Clapeyron equation, the slope of the reaction line between coesite and stishovite is calculated. The position of the reaction line, coesite $\rightarrow$ stishovite, is calculated, using the point on the coesite-stishovite equilibrium curve at $130 \pm 15 \mathrm{~kb}$ and $1600 \pm$ $100^{\circ} \mathrm{C}$ which was estimated by Stishov [1963] from synthesis experiments. The standard enthalpy of stishovite is then obtained from equation 1, using, as before, the change in free energy between the equilibrium pressure (96 kb) and zero pressure, which is given in Figure 2. The uncertainties indicated in Table 2 for $\Delta H_{298}{ }^{\circ}$ for stishovite reflect the uncertainty in the position of the coesite $\rightarrow$ stishovite equilibrium point.

The standard entropy of $\mathrm{Mg}_{2} \mathrm{SiO}_{4}$ (spinel) was obtained by using Ringwood and Major's [1966b] density in a density-entropy correlation of five normal spinel compounds (Figure 3 ). (It should be noted that the available standard entropy data for some of the inverse spinel compounds, such as $\mathrm{Fe}_{2} \mathrm{TiO}_{4}$ and $\mathrm{NiFe}_{2} \mathrm{O}_{4}$, could not be so correlated with density.) The slope and position of the reaction line for $\mathrm{Mg}_{2} \mathrm{SiO}_{4}$ (olivine) transforming to spinel is then obtained, using the estimates of the entropy and volumes of spinel with those for olivine in the Clausius-Clapeyron relation and the point on the reaction line at $150 \pm 10 \mathrm{~kb}$ and $800 \pm$ $10^{\circ} \mathrm{C}$ [Akimoto and Fujisawa, 1966], respectively. The standard enthalpy of spinel is calculated by using equation 1 and the value of $-\int \Delta V d p$ (Figure 2) that corresponds to the equilibrium pressure $(110 \mathrm{~kb})$. The uncertainty in $\Delta H_{288}{ }^{\circ}$ reflects the uncertainty in the location of the olivine $\rightarrow$ spinel boundary at $800^{\circ} \mathrm{C}$. The 


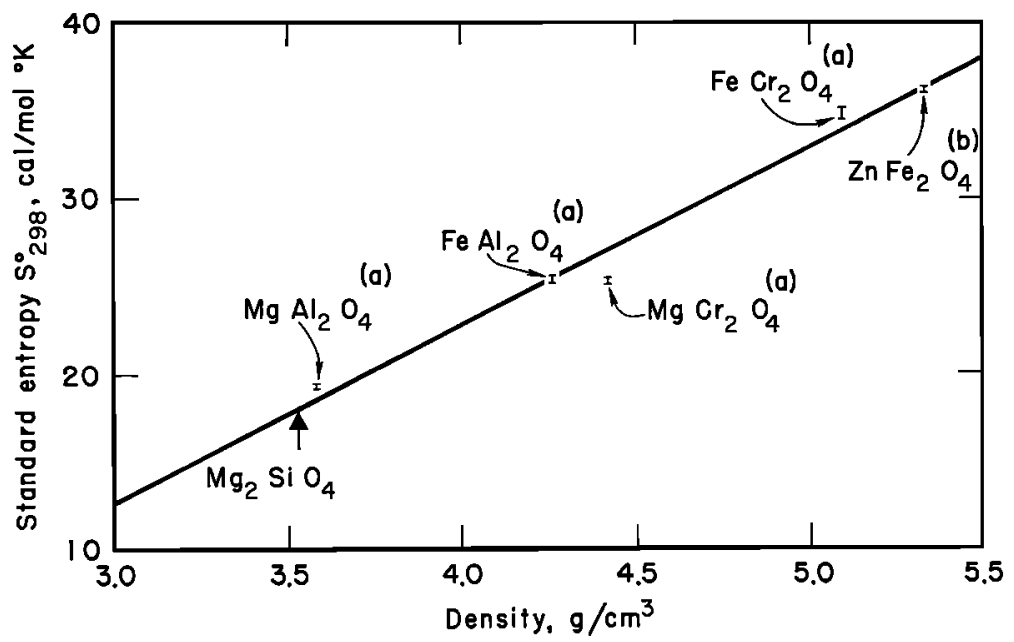

Fig. 3. Density-standard entropy, correlation for normal spinels: (a) Kelley and King [1961], (b) Westrum and Grimes [1957].

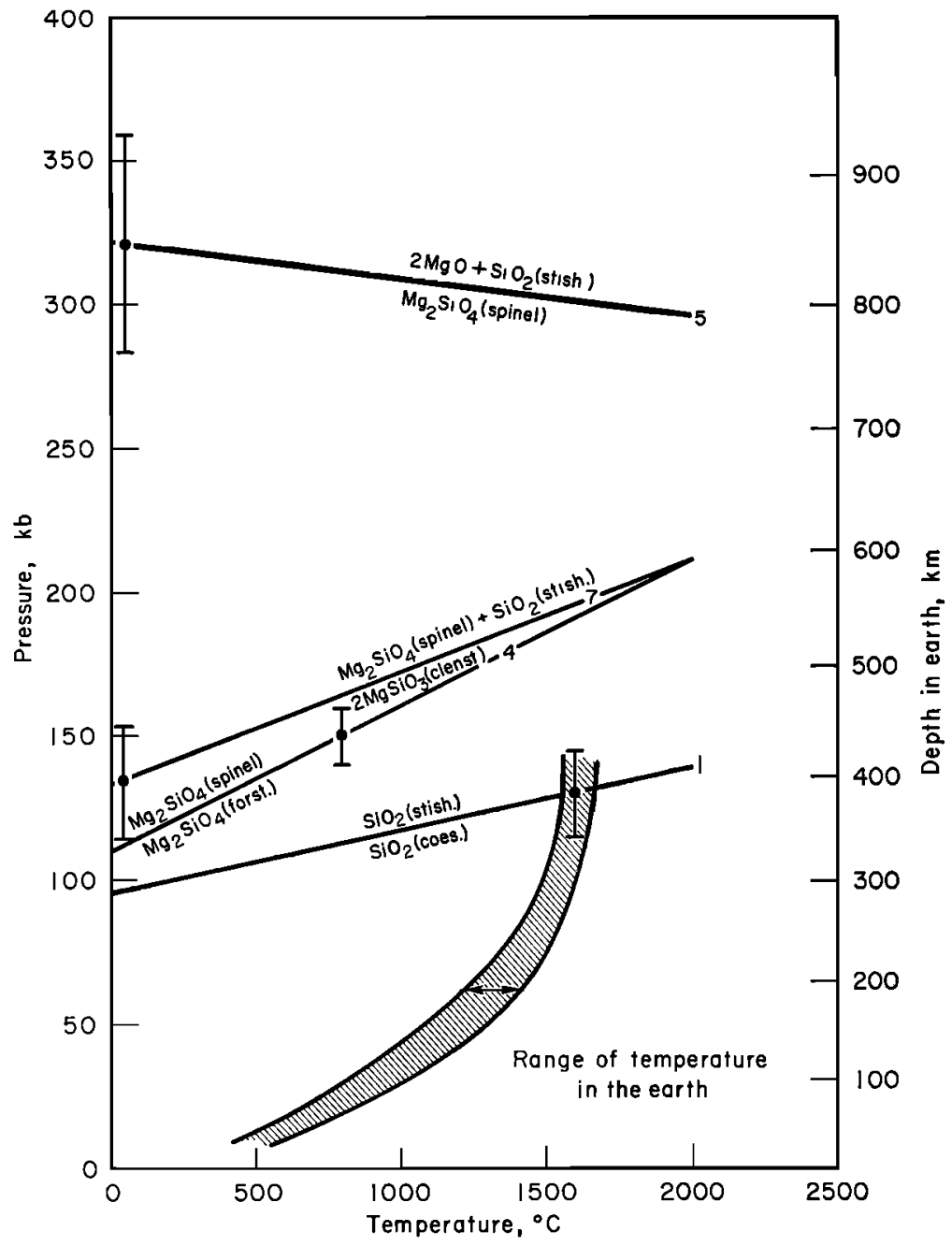

Fig. 4. Pressure-temperature diagram showing relation of calculated reaction lines to Clark and Ringwood's [1964] estimate of temperature range in the earth. Depth-pressure correlation [Birch, 1964]. (Numbers refer to reactions listed in Table 1; abbreviations are defined in Figure 2.) 
markedly steep reaction line which we calculate is in qualitative agreement with the slope of the reaction line $d p / d T=0.077 \mathrm{~kb} /{ }^{\circ} \mathrm{C}$ inferred by Dachille and Roy [1960] from their study of the system $\mathrm{Mg}_{2} \mathrm{GeO}_{4}-\mathrm{Mg}_{2} \mathrm{SiO}_{4}$.

Calculated reactions lines. The position and slope in the $p-T$ plane of reactions 1-7 (Table 1) are calculated with the data given in Tables 2 and 3 , using equation 1 and calculated values of $\Delta F_{298}^{\circ}$ versus $p$ (Figure 2). Equilibrium reaction lines are plotted in Figure 4 relative to the temperature estimate for the mantle obtained by Clark and Ringwood [1964]. The reaction line calculated for the breakdown of forsterite to $\mathrm{MgO}$ and stishovite occurs at approximately $20 \%$ higher pressure than previous estimates of this reaction by MacDonald [1962] and Ringwood [1962]. Since this reaction, even at $2000^{\circ} \mathrm{C}$, lies well above the pressure stability range of forsterite, it does not appear likely that it would take place in the earth's mantle. Similarly, the breakdown of clinoenstatite to either periclase or forsterite and stishovite (reactions 3 and 6) takes place at pressures far higher than the pressures required for the breakdown of clinoenstatite to $\mathrm{Mg}_{2} \mathrm{SiO}_{4}$ (spinel) and stishovite (reaction 7). It appears, rather, that the reactions $\mathrm{Mg}_{2} \mathrm{SiO}_{4}$ (olivine) $\rightarrow \mathrm{Mg}_{2} \mathrm{SiO}_{4}$ (spinel), $\mathrm{Mg}_{2} \mathrm{SiO}$ ( (spinel) $\rightarrow 2 \mathrm{MgO}+\mathrm{SiO}_{2}$, and $2 \mathrm{MgSiO}_{3} \rightarrow \mathrm{Mg}_{2} \mathrm{SiO}_{4}$ (spinel) $+\mathrm{SiO}_{2}$ take place along $p=110+$ $0.024 T, p=321-0.013 T$, and $p=133+$ $0.039 T$, respectively. The principal uncertainties in the position of these reaction lines arise from the uncertainties in the measured or calculated values of $\Delta H_{289}^{\circ}$. The results are relatively insensitive to errors in estimating the density of mineralogic species. For example, decreasing the density of $\mathrm{Mg}_{2} \mathrm{SiO}_{4}$ (spinel) by $1 \%$ lowers the position of reaction 4 by $14 \mathrm{~kb}$.

The effect on the present results of transformation of clinoenstatite and $\mathrm{Mg}_{2} \mathrm{SiO}_{4}$ (spinel) to other polymorphs such as the corundum and hexagonal nickel-arsenide type structures, respectively, should be investigated when data on these polymorphs become available.

Note added in proof: Recent studies [Akimoto and Syuno, 1967] of the high pressure stability of the titanate spinels $\left(\mathrm{Mg}_{2} \mathrm{TiO}_{4}\right.$, $\mathrm{Fe}_{2} \mathrm{TiO}_{4}$, and $\mathrm{Co}_{2}{ }^{\mathrm{T}} \mathrm{TiO}_{4}$ ) suggest that $\mathrm{Mg}_{2} \mathrm{SiO}_{4}$ (spinel structure) may react at high pressures to form $\mathrm{MgSiO}_{3}$ (ilmenite structure) and $\mathrm{SiO}$ (halite structure).

Acknowledgments. We appreciate the help of Dr. E. G. King of the Berkeley Thermodynamics Laboratory for bringing several thermochemical studies to our attention.

The National Science Foundation provided support for one of us (Y.S.) under grant GP 5422.

\section{References}

Ahrens, T. J., High pressure electrical behavior and equation of state of magnesium oxide from shock wave measurements, J. Appl. Phys., 37, 2532-2541, 1966.

Ahrens, T. J., J. T. Rosenberg, and Y. Syono, Shock compression measurements on anorthosite, augite, diopside, olivine, and microcline and their application to the pressure-volume relations in rocks (abstract), Trans. Am. Geophys. Union, 47, 174, 1966.

Akimoto, S., and H. Fujisawa, Olivine-spinel transition in the system $\mathrm{Mg}_{2} \mathrm{SiO}_{4}-\mathrm{Fe}_{2} \mathrm{SiO}_{4}$ at $800^{\circ} \mathrm{C}$, Earth Planetary Sci. Letters, 1, 237-240, 1966.

Akimoto, S., and Y. Ida, High-pressure synthesis of $\mathrm{Mg}_{2} \mathrm{SiO}_{4}$ spinel, Earth Planetary Sci. Letters, 1, 358-359, 1966.

Akimoto, S., and Y. Syono, High-pressure decomposition of some titanate spinels, Tech. Rept., Inst. Solid State Physics, Sir. A(2), March 1967.

Albers, W., and C. J. M. Rooymans, High pressure polymorphism of spinel compounds, Solid State Comm., 3, 417-419, 1965.

Anderson, D. L., Recent evidence concerning the structure and composition of the earth's mantle, Phys. Chem. Earth, 6, 1-131, 1965.

Barron, T. H. K., W. T. Berg, and J. A. Morrison, On the heat capacity of crystalline magnesium oxide, Proc. Roy. Soc. London, A, 250, 70-83, 1959.

Birch, F., Elasticity and constitution of the earth's interior, J. Geophys. Res., 57, 227-286, 1952.

Birch, F., The velocity of compressional waves in rocks to 10 kilobars, 1, J. Geophys. Res., 65, 1083-1102, 1960.

Birch, F., The velocity of compressional waves in rocks to 10 kilobars, 2, J. Geophys. Res., 66, 2199-2224, 1961.

Birch, F., Density and composition of mantle and core, J. Geophys. Res., 69, 4377-4388, 1964.

Boyd, F. R., and J. L. England, The quartzcoesite transition, J. Geophys. Res., 65, 749-756, 1960.

Bridgman, P. W., The compression of 39 substances to $100,000 \mathrm{~kg} / \mathrm{cm}^{2}$, Proc. Am. Acad. Arts Sci., 76, 55-70, 1948.

Bridgman, P. W., Linear compression to 30,000 $\mathrm{kg} / \mathrm{cm}^{2}$, including relatively incompressible substances, Proc. Am. Acad. Arts Sci., 77, 187-234, 1949.

Bullen, K. E., Seismology and the broad structure of the earth's interior, Phys. Chem. Earth, 1, 68-93, 1956. 
Clark, S. P., Jr., Ed., Handbook of Physical Constants, Geol. Soc. Am. Mem., 97, 1966.

Clark, S. P., Jr., and A. E. Ringwood, Density distribution and constitution of the mantle, Rev. Geophys., 2, 35-88, 1964.

Dachille, $F$., and $R$. Roy, High pressure studies of the system $\mathrm{Mg}_{2} \mathrm{GeO}_{4}-\mathrm{Mg}_{2} \mathrm{SiO}_{4}$ with special reference to the olivine-spinel transition, $A m$. J. Sci., 258, 225-246, 1960.

Good, W. D., The heat of formation of silica, J. Phys. Chem., 66, 380-381, 1962.

JANAF Tables, Joint Army, Navy, Air Force tables of thermochemical data, compiled by Dow Chemical Company, Thermal Laboratory, Midland, Michigan, 1960.

Kelley, K. K., and E. G. King, Contribution to the data on theoretical metallurgy, 14, Entropies of the elements and inorganic compounds, $U$. $S$. Bur. Mines Bull., 592, 1961.

MacDonald, G. J. F., On the internal constitution of the inner planets, J. Geophys. Res., 67, 2945-2974, 1962.

McQueen, R. G., J. N. Fritz, and S. P. Marsh, On the equation of state of stishovite, J. Geophys. Res., 68, 2319-2322, 1963.

Perez-Albuerne, E. A., and H. G. Drickamer, The effect of high pressures on the compressibilities of seven crystals having the $\mathrm{NaCl}$ or $\mathrm{CsCl}$ structures, J. Chem. Phys., 43, 1381-1387, 1965.

Ringwood, A. E., Mineralogical constitution of the deep mantle, J. Geophys. Res., 67, 40054010, 1962.

Ringwood, A. E., and A. Major, High-pressure transformation of $\mathrm{FeSiO}_{3}$ pyroxene to spinel plus stishovite, Earth Planetary Sci. Letters, 1, 135-136, 1966a.
Ringwood, A. E., and A. Major, Synthesis of $\mathrm{Mg}_{2} \mathrm{SiO}_{4}-\mathrm{Fe}_{2} \mathrm{SiO}_{4}$ spinel solid solutions, Earth Planetary Sci. Letters, 1, 241-245, $1966 b$.

Sclar, C. B., and L. C. Carrison, High pressure synthesis of a spinel on the join $\mathrm{Mg}_{2} \mathrm{SiO}_{4}-\mathrm{Fe}_{2}$ $\mathrm{SiO}_{\iota}$, Trans. Am. Geophys. Union, 47, 207, 1966.

Sclar, C. B., L. C. Carrison, and C. M. Schwartz, High pressure reaction of clinoenstatite to forsterite plus stishovite, J. Geophys. Res., 69, 325-330, 1964.

Simmons, G., Velocity of shear waves in rocks to 10 kilobars, J. Geophys. Res., 69, 1123-1130, 1964.

Stishov, S. M., Equilibrium line between coesite and the rutile-like modification of silica, Dokl. Akad. Nauk SSSR, 148, 1186-1188, 1963.

Torgesson, D. R., and Th. G. Sahama, A hydrofluoric acid solution calorimeter and the determination of the heats of formation of $\mathrm{Mg}_{2} \mathrm{SiO}_{4}, \mathrm{MgSiO}_{\mathrm{a}}$ and $\mathrm{CaSiO}_{3}, J . A m$. Chem. Soc., 70, 2156-2160, 1948.

Wackerle, J., Shock-wave compression of quartz, J. Appl. Phys., 38, 922-987, 1962.

Westrum, E. F., Jr., and D. M. Grimes, Low temperature heat capacity and thermodynamic properties of zinc ferrite, J. Phys. Chem. Solids, \$, 44-49, 1957.

Wise, S. S., J. L. Margrave, H. M. Feder, and W. N. Hubbard, The heat of formation of silica and silicon tetrafluoride, J. Phys. Chem, 66, 381, 1962.

(Received September 16, 1966; revised March 27, 1967.) 